Pak. j. sci. ind. res. Ser. B: biol. sci. 2021 64A(3) 231-243

\title{
Seasonal and Spatial Variations of Iron and Zinc Values in Meadows with a Semi-Arid Climate
}

\author{
Humayun Bashir*, Zafar Iqbal Khan and Kafeel Ahmad \\ Department of Botany, University of Sargodha, Pakistan
}

(received July 3, 2019; revised September 16, 2019; accepted February 2, 2020)

\begin{abstract}
Seasonal changes in the climate, as well as in plants and species living in this environment, which causes serious problems. Current work was carried out to evaluate the seasonal impact on the concentration of iron (Fe) and zinc $(\mathrm{Zn})$ in soil, forages and animals. A semi arid dry climatic area of Pakistan was selected to find out the seasonal effects on soil and availability of $\mathrm{Zn}$ and $\mathrm{Fe}$, and its translocation to forages and animals. Twenty seven forages were collected and 320 ruminant samples collected from two sites in four seasons. Effect of spatial-temporal variations were studied on the ruminants of four physiological stages (Does, Bucks, Wether and Juvenile). Different sources from goats including blood, feces and urine were collected for the analysis of $\mathrm{Zn}$ and Fe. Results showed that both elements in soil were significantly $(\mathrm{P}<0.05)$ affected by season and site $\mathrm{x}$ season. In forages, only site showed significant effect on Fe and $\mathrm{Zn}$, while $\mathrm{Zn}$ was affected non-significantly $(\mathrm{P}>0.05)$ by season and site $\mathrm{x}$ season. $\mathrm{Zn}$ and $\mathrm{Fe}$ in goats were non-significantly affected by season and source $\mathrm{x}$ stages, while significantly affected by sites and sources. All values of both elements were in safe limits except deficiency of Fe (1.69 to $2.33 \mathrm{mg} / \mathrm{L}$ ) in blood. Results of health indices were also in the limits. Current work encircles the spatiotemporal effects on mineral availability in the food chain and also concern the health effects related to ruminant health.
\end{abstract}

Keywords: iron, zinc, season, semi-arid, spatio-temporal

\section{Introduction}

Heavy metals are very important environmental factors and toxicity of heavy metals cause severe harms in organisms and the surrounding environment. In many biochemical and physiological metals play vital role and their toxicity depends on plant species, chemical form and concentration (Ackova, 2018). Heavy metals, although essential, are needed in minor concentrations by plants. Some of these metals such as $\mathrm{Fe}$ and $\mathrm{Cu}$ have a basic association with activation and stabilization of enzymes by their interaction with proteins (White and Greenwood, 2013). These metals are said to be redoxactive and play pivotal roles in key physiological functions, e.g., chlorophyll biosynthesis, photosynthesis, carbon and nitrogen metabolism, respiration, and defense against reactive oxygen species (Hansch and Mendel, 2009). Iron is stored intracellularly as ferritin in the plastids (Ravet et al., 2009) being a fundamental structural component of a number of heme proteins (cytochromes, catalase, reductase and peroxidase), $\mathrm{Fe}$ S proteins (ferredoxin, aconitase and SOD), siroheme proteins (nitrite reductase and sulfite reductase) and other Fe-containing proteins (lipoxygenase) (Page and Feller, 2015). Iron is also found to be associated with

*Author for correspondence; E-mail: humayunuos@gmail.com regulation of transcription and translation and biosynthesis of phytohormones such as gibberellins, ethylene and jasmonic acid (Hansch and Mendel, 2009).

Iron is an important micro-mineral that is present in both animals as well as in plants. Fe is involved in essential fundamental processes such as photosynthesis and respiration and co-factor for a variety of enzymes (Sperotto et al., 2010). Fe is the central atom present in heme proteins such as cytochrome oxidase, catalase, nitrate reductase, and peroxidase, in siroheme proteins such as sulphite and nitrite reductase, in $\mathrm{Fe}-\mathrm{S}$ proteins such as ferredoxin and other $\mathrm{Fe}$ containing proteins such as lipoxygenase. $\mathrm{Fe}$ is stored intracellularly processed in the form of ferritin in plastids (Page and Feller, 2015). Fe deficiency can lead to growth, retardation, chlorosis and even death of the plant. Despite its abundance in the earth's crust, bioavailable Fe concentration is generally low because of the formation of insoluble Fe oxides (Ricachenevsky and Sperotto, 2014). The Fe level in the soil is mostly within an appropriate amount, but Fe may increase to toxic level in the plant. Fe toxicity in plants causes the microbial reduction of insoluble Fe (Dorlodot et al., 2005). Iron toxicity in plant cause to reduce the yield and photo- 
synthetic activity, but increase the ascorbate peroxidise activity and oxidative stress (Nagajyoti et al., 2010). Iron toxicity in animal is mostly due to excessive use of iron supplements. Approximately $70 \%$ of iron is available in the form of hemoglobin and about $5 \%$ to $10 \%$ is found in myoglobin. Fe is carried in the serum by transferrin. The binding capacity of the transferrin is closed due to high dose of Fe and serum Fe level increases rapidly (Oruc et al., 2009). Most animals are naturally well susceptible to Fe toxicity. Oral dosages of Fe greater than $150 \mathrm{mg} / \mathrm{Kg}$, body weight cause toxicity in animals (Osweiler et al., 1985).

Zinc $(\mathrm{Zn})$ is a mobile element in plants and can be transported by means of phloem to the growing parts of the plant. $\mathrm{Zn}$ is essential for the synthesis of chlorophyll and activates some of the enzymes and these include carbonic anhydrase, $\mathrm{Cu}-\mathrm{Zn} \mathrm{SOD}$, and metalloproteinase (Page and Feller, 2015). Biosynthesis of auxin, starch and chloroplast is also indebted to the presence of $\mathrm{Zn}$. Deficiency of the metal can cause chlorosis because of its involvement in the synthesis of chlorophyll. Leaves become mottled and appear bronze in colour. Abnormal growth of roots is also associated with $\mathrm{Zn}$ deficiency (Soetan et al., 2010). Zn is usually linked to stimulation of the immune system of animals, but it has reported to weaken the immune system and reduces the levels of calcium in HIV-positive men (Wood, 2000).

Excess of Zn slow plants growth and contributes to chlorophyll degradation in young leaves. Older leaves are affected if the duration of exposure prolongs. Chlorosis could be explained on the basis of Fedeficiency induced by $\mathrm{Zn}$, as hydrated $\mathrm{Zn}$ and Fe ions are similar in size (Kalaivanan and Ganeshamurthy, 2016). Zn toxicity can also lead to deficiency of Mn, $\mathrm{Cu}$ and $\mathrm{P}$, characterised by development of typical purple-red colour of the leaves (Lee et al., 1996). Level of $\mathrm{Zn}$ acceptable in plants is $300-400 \mathrm{mg} / \mathrm{Kg}$ dry weight but its level varies according to growth stages and plant species. The $\mathrm{Zn}$ level remains within limits, for the most parts, but high level of $\mathrm{Zn}$ for long period enhance the $\mathrm{Zn}$ level in plants. Zn toxicity in plants can affect the plants in many ways, e.g. extreme chlorosis, decrease growth of shoots and imbalance in metabolic activities (Ackova, 2018; Versieren, 2017).

Cattle provide organic manure and on-farm power for agricultural sector. Animal products are a rich source of essential micronutrients (such as $\mathrm{Fe}$ and $\mathrm{Zn}$ ) and vitamins (such as Vit. A and Vit. B-12). Thus, providing a nutritious and balanced diet to the inhabitants of under-developed and developing countries (McAfee et al., 2010). Purpose of the present study was to evaluate the seasonal effects on the translocation of Fe and $\mathrm{Zn}$. Current work also aimed to check any toxicity in soil, forages and livestock and also encircle the effects of seasons and sites in food chain of semi arid environment. Present work comprehensively describe the metals availability and transfer from soil, forages to small ruminants in four seasons of year. Different indices also shows the amount of metal transfer in environment. With the help of this work we can easily detect the seasonal and spatial impact on metal availability and its effect on forages and livestock. It will provide a base line data for livestock of semi arid region and we can know the deficiency and toxicity of that metals in livestock. So, we will be able to recommend mineral mixture on the basis of this data and improve the forages and livestock of semi arid region.

\section{Materials and Methods}

Study site. The present research was conducted in semi - arid regions of Pakistan. District Bhakkar is present in semi-arid region and average annual temperature of Bhakkar is $24.6^{\circ} \mathrm{C}$. Average rainfall of study site is $213 \mathrm{~mm}$. This study was conducted at two sites in year 2017-2018. Site 1 consists of Tehsil Bhakkar and Tehsil Mankera. The site 2 consists of Tehsil Darya Khan and Khan Kaloor Kot (Fig. 1). Samples for forages and fodders were collected randomly from 10 plots in each site and made a one unit sample or replicate. All sampling was done in four different seasons viz., summer, winter,

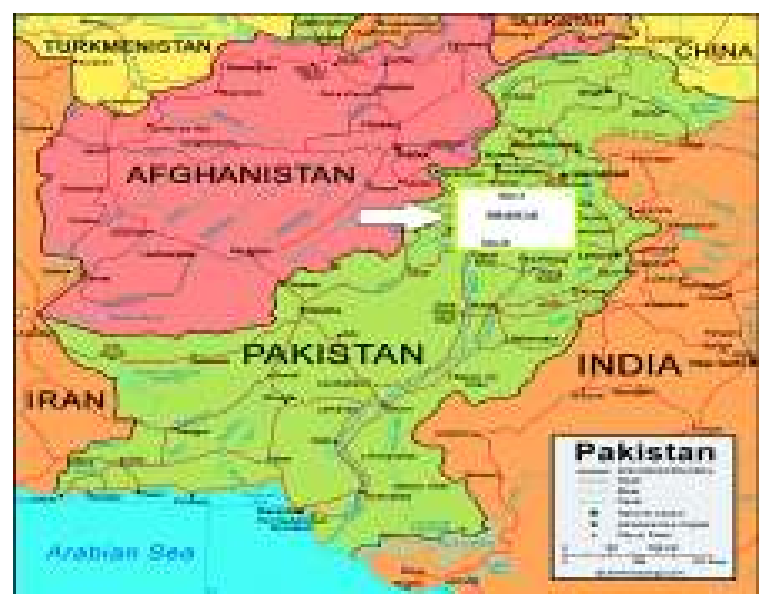

Fig. 1. Map of study site. 
autumn and spring. Five replicates of each forage and fodder were collected and brought to Department of Botany, University of Sargodha for further analysis. Goats were divided into four groups or stages, Does (Female), Bucks (Male), Wether (Castrated), Juvenile (6 month) 10 in each group and sampling of three sources (Blood, Urine and Feces) from these different goat stages were done. All goats were one year old, except juvenile which were 6 months old.

Soil. Soil samples (100 $\mathrm{mg}$ each) were collected from every 10 plot of the site, where forage/fodders were collected and made into one composite sample. The selected places were dug up to $12-15 \mathrm{~cm}$ deep partially containing all the layers by a stainless steel auger. Five composite samples were prepared and dried in air, and put in forced air oven for $47 \mathrm{~h}$ at a temperature of 72 ${ }^{\circ} \mathrm{C}$. These collected samples were air dried, stored in labeled, sealed paper bags and placed in an incubator for 5 days at a temperature of $70{ }^{\circ} \mathrm{C}$ (Rhue and Kidder, 1983).

Forages and fodders. The available forages and fodders samples on which the goats graze were collected (Table 1) from the same site of the soil samples were taken by using sterilized apparatus. Then collected samples were air dried, stored in labeled, sealed paper bags and placed in an incubator for 5 days at a temperature of $70^{\circ} \mathrm{C}$ (Sanchez, 1976).

Blood-serum sample collection. Blood samples were collected from four categories of the goat Does, Bucks, Wether, and Juvenile (10 in each group). A total of 20 $\mathrm{mL}$ blood was taken from the jugular vein of each goat in heparin vile sterile plastic test tubes which were placed in slanting position for an hour to let the serum ooze out. After blood collection the serum was separated from plasma by centrifugation. Then the serum was aspirated carefully with a pipette, put in small labeled voiles and placed in the freezer at $-20^{\circ} \mathrm{C}$ till analysis (Kamada et al., 2000).

Urine and feces. Urine and fecal samples of goats were also collected by using standard methods described by Kamada et al. (2000).

Sample size calculation for animals. The sample size for the ruminants used in this study was calculated by using the equation for a study comparing two means (Eng, 2003) as shown below:

$$
\mathrm{N}=4 \sigma^{2}\left(\mathrm{Z}_{\text {crit }}+\mathrm{Z}_{\mathrm{pwr}}\right) / \mathrm{D}^{2}
$$

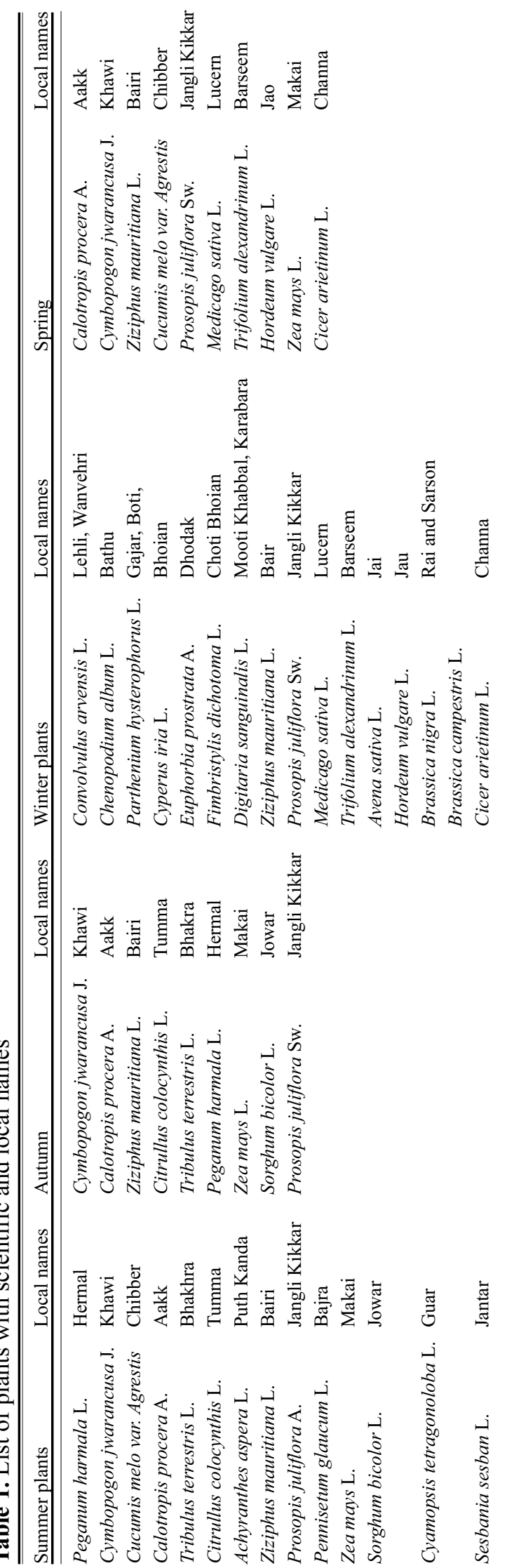


By applying above formula, a total of 80 goats were recruited in the study. Bhakkar District was split into two parts (Site 1 and Site 2). Fourty of these goats were from Site 1 and the same number for site 2. Fourty from each site were divided into four groups Does, Bucks, Wether, Juvenile (10 in each group).

Therefore, the total number of samples for the four seasons was:

80 goats $\mathrm{x} 4$ seasons $=320$ ruminants

Sample preparation and analytical procedure to determine minerals. $60 \mathrm{~mL}$ liquid samples of bloodserum and urine, soil, forages, fodder and feces were prepared after digestion by following standard procedure given by Kamada et al. (2000). Mineral analysis of all samples was carried out by using an Atomic Absorption Spectrophotometer Perkin-Elmer AAS-5000 (PerkinElmer Corp., 1980) after wet digestion. Samples were checked for the concentration of iron $(\mathrm{Fe})$ and zinc (Zn).

Statistical analysis. Data visualization was performed with the help of combined box plots using ggplot2 package in software R. Analysis of variance (ANOVA) (Steel et al., 2006) along with least significant difference (LSD) test was applied using statistix 8.1.

Bio-concentration factor. The determination of bioconcentration is brought about by using the formula devised by Cui et al. (2004).

$$
\begin{aligned}
& \text { Bio-concentration factor (Soil to Forage) }=\frac{M(\text { Forage })}{M(\text { Soil })} \\
& \text { Bio-concentration factor (Forage to Goats) }=\frac{(M) \text { Goats }}{(M) \text { Forage }}
\end{aligned}
$$

where:

(M)Forage $=$ Concentration of metal $(\mathrm{mg} / \mathrm{Kg})$ in forage; (M)Soil = Concentration of metal $(\mathrm{mg} / \mathrm{Kg})$ in soil; (M)Goat = Concentration of metal $(\mathrm{mg} / \mathrm{Kg})$ in goat; Pollution Load Index (PLI). Pollution Load Index is determined by the following formula: (Liu et al., 2005).

$$
\text { Pollution Load Index }=\frac{(\mathrm{M}) \mathrm{IS}}{(\mathrm{M}) \mathrm{RS}}
$$

where:

(M)IS = Concentration of metal $(\mathrm{mg} / \mathrm{Kg})$ in sample soil; $(\mathrm{M}) \mathrm{RS}=$ Reference value of that metal in soil.
Enrichment factor (EF). Enrichment factor is calculated by the formula of Buat-Menard and Chesselet (1979).

$$
\text { Enrichment factor }(\mathrm{EF})=\frac{\begin{array}{c}
\text { Conc. of metal in forage/Conc. } \\
\text { of metal in soil) sample }
\end{array}}{\left(\begin{array}{c}
\text { Conc. of metal in forage } \div \text { Conc. } \\
\text { of metal in soil) standard }
\end{array}\right.}
$$

\section{Results and Discussions}

Iron (Fe). Soil. The analysis of variance of Fe values in soil samples exhibited significant $(\mathrm{P}<0.05)$ variation in season and site $\mathrm{x}$ season, but non-significant $(\mathrm{P}>$ 0.05 ) variation in sites (Table 2). Results showed that Fe values in soil samples were ranged from 12.01 to $17.44 \mathrm{mg} / \mathrm{Kg}$ in all sampling seasons at both sites. The minimum concentration of $\mathrm{Fe}$ in the soil was observed in season 1 at site 1 and maximum concentration was observed in season 4 at site 2 (Fig. 2). The present study showed that $\mathrm{Fe}$ values in soil samples were lower than the critical level $(150 \mathrm{mg} / \mathrm{Kg})$ described by NRC (2001) and WHO (2000). Fe values were also lower than the values given by Shisia et al. (2013). Low concentration of $\mathrm{Fe}$ in the soil is closely associated with the composition of the parent material from which soil made. It is known very well that parent material of soil determines the chemical properties of soil (Irmak et al., 2007). Organic matter, mineralogy and texture of soil show effect on the $\mathrm{Fe}$ availability in soil and thus, direct relation of knowledge between soil chemistry and mineralogy with plant nutrition and fertility is compulsory (Mielki et al., 2016).

Limited root growth and microbial activity in wet and cool soils in early growing season lead towards the deficiency of Fe in soil. On the other hand, high microbial activity, warm soil and high root proliferation increase the Fe level in soil and also its availability to plants. (Schulte, 2004). Iron deficiency in the present study may be due to the low microbial activity or non availability of $\mathrm{Fe}$ in soluble form.

Forages. Fe values in forages showed significant $(\mathrm{P}<$ 0.05 ) variations in site, season and site $x$ season (Table 2). Concentrations of Fe determined in forage samples were ranged from 27.04 to $33.26 \mathrm{mg} / \mathrm{Kg}$ in all sampling seasons and sites. Lowest Fe value in forages was observed in season 1, at site 1 and the highest value was observed in season 4, at site 2 (Fig. 2). Present investigation showed that $\mathrm{Fe}$ values in forages were lower than the level (40 mg/Kg) given by WHO (1998). 
Table 2. Analysis of variance of Fe and $\mathrm{Zn}$ for soil, forage and goats

\begin{tabular}{|c|c|c|c|c|c|c|c|c|}
\hline \multirow{3}{*}{ Metals } & \multicolumn{8}{|c|}{ Analysis of variance of metals for soil and forages } \\
\hline & \multicolumn{4}{|c|}{ Soil } & \multicolumn{4}{|c|}{ Forages } \\
\hline & Site & Season & Site $\mathrm{x}$ Season & Error & Site & Season & Site $\mathrm{x}$ season & Error \\
\hline df & 1 & 3 & 3 & 482 & 1 & 3 & 3 & 482 \\
\hline $\mathrm{Fe}$ & $53.717 \mathrm{~ns}$ & $179.642 * * *$ & $244.998 * * *$ & 33.351 & $3492.736 * * *$ & $16.619 * * *$ & $10.805^{* *}$ & 2.932 \\
\hline $\mathrm{Zn}$ & $61.655^{* * *}$ & $70.782 * * *$ & $23.389 * * *$ & 0.940 & $34.989 * * *$ & $1.875 \mathrm{~ns}$ & $1.610 \mathrm{~ns}$ & 5.212 \\
\hline \multicolumn{9}{|c|}{ Analysis of variance of metals for goats in site $\mathrm{x}$ season and source $\mathrm{x}$ stage } \\
\hline Metals & Site & Season & Site $\mathrm{x}$ Season & Error & Source & Stage & Source $\mathrm{x}$ stage & Error \\
\hline df & 1 & 3 & 3 & 952 & 2 & 3 & 6 & 948 \\
\hline $\mathrm{Fe}$ & $775.27 * * *$ & $6.6528 \mathrm{~ns}$ & $6.60 \mathrm{~ns}$ & 12.865 & $5895.669 * * *$ & $1.182 \mathrm{~ns}$ & $0.144 \mathrm{~ns}$ & 1.336 \\
\hline $\mathrm{Zn}$ & $59.70 * * *$ & $0.0113 \mathrm{~ns}$ & $0.46^{* * *}$ & 0.018 & $1.890 * * *$ & $0.538 * * *$ & $0.000 \mathrm{~ns}$ & 0.077 \\
\hline
\end{tabular}

$* * *=$ significant at 0.001 levels; $* *=$ significant at 0.01 levels; $*=$ significant at 0.05 levels; $n s=$ non-significant at above 0.05 levels.

Fe concentrations in forages of the present study were lower than the concentration of forages reported by Shisia et al. (2013) and also lower than the minimum requirement level of ruminants described by McDowell et al. (1982). The higher Fe level in forages than the present study is reported by Khan et al. (2004).

Deficiency of Fe in plants occurs only due to the soil in which plants grow. The high amount of calcium and bicarbonate cause the Fe deficiency in the soil. High level of $\mathrm{CaCO}_{3}$ and $\mathrm{pH}$ can also be one of reasons to reduce the iron availability to plants because only one unit increase of $\mathrm{pH}$ reduce the $\mathrm{Fe}$ solubility 1000 -folds (Incesu et al., 2015). As Fe is immobile in plants, young leaves appear as the first sign of deficiency symptoms. Fe deficiency also causes chlorosis in young leaves. Minor deficiency of iron is often confused with manganese deficiency and cause interveinal chlorosis (Schulte, 2004). Even though $\mathrm{Fe}$ is available in high amount in soil, plants suffer from deficiency of $\mathrm{Fe}$ because of its low solubility (Ma and Ling, 2009). Fe deficiency in the present forages might be due to high $\mathrm{pH}$ Level, soil chemical properties and its low solubility.

Goats. Analysis of variance of Fe values in the goats showed significant $(\mathrm{P}<0.05)$ variation in sites but nonsignificant $(\mathrm{P}>0.05)$ variation in season and site $\mathrm{x}$ season (Table 2). Value of $\mathrm{Fe}$ in goats varied from 5.79 to $8.11 \mathrm{mg} / \mathrm{Kg}$ during all seasons at both sites. Season 1 of site 1 showed the lowest values of $\mathrm{Fe}$ and season 2 of site 2 showed the highest value of Fe (Fig. 2). Variance data of $\mathrm{Fe}$ showed that the source had a significant effect $(\mathrm{P}<0.05)$, but the stage and source

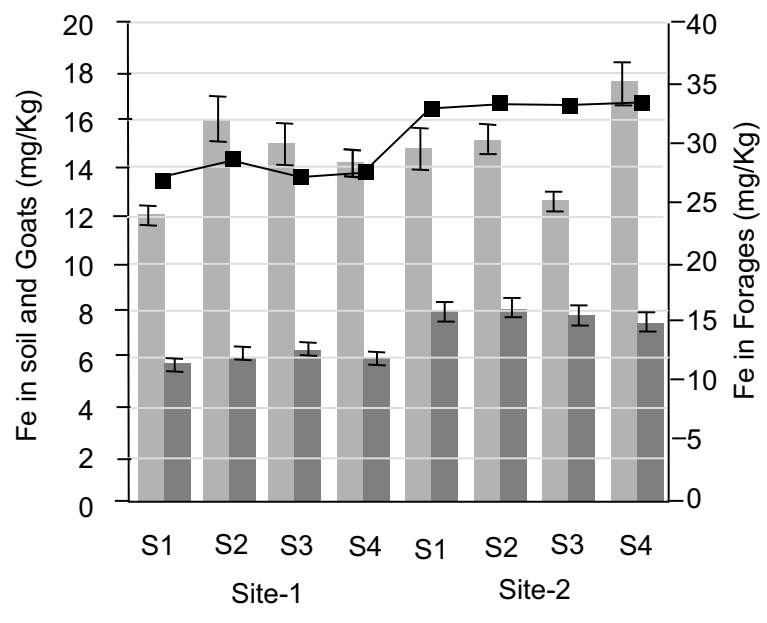

Soil Goats - Forage

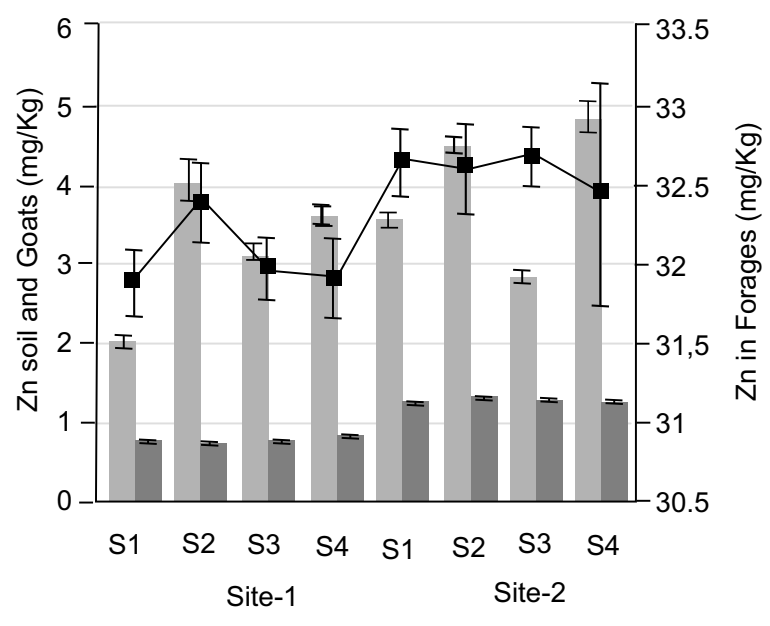

Soil Goats - Forage

Fig. 2. Mean concentration and comparison of $\mathrm{Fe}$ and $\mathrm{Zn}$ transfer from soil to forage to goats. 
$\mathrm{x}$ stage had non-significant $(\mathrm{P}>0.05)$ effect on $\mathrm{Fe}$ values (Table 2). Fe values in all sources and stages was ranged from $2.00 \mathrm{mg} / \mathrm{Kg}$ to $9.72 \mathrm{mg} / \mathrm{Kg}$ (Table 3). Minimum level of $\mathrm{Fe}$ was observed in blood of bucks and maximum was observed in feces of does.

Box plot depicted that $\mathrm{Fe}$ concentration in blood plasma was observed in between 1.69 to $2.33 \mathrm{mg} / \mathrm{L}$ during all seasons at both sites. Season 1 of site 1 showed the lowest Fe value and season 2 of site 2 showed the

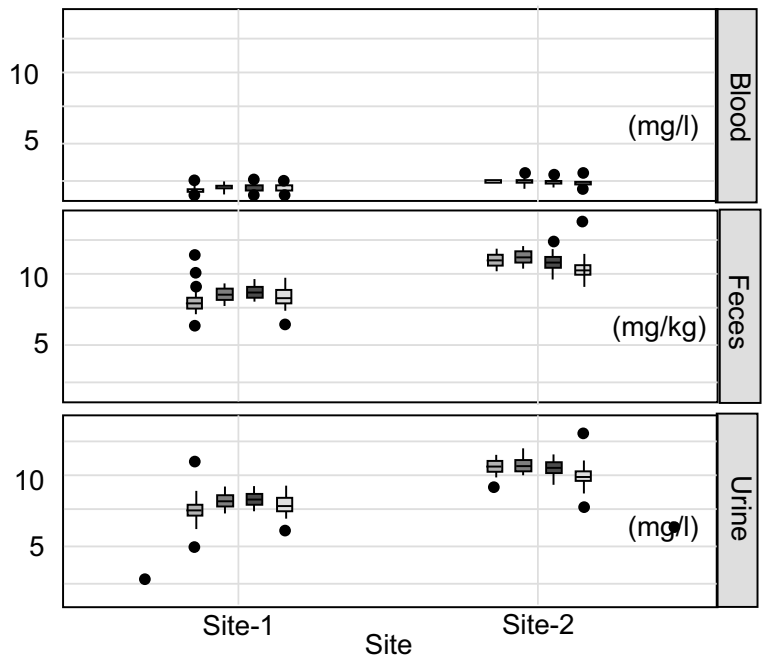

Fe Season

宇 $\mathrm{S} 1$ 宇 $\mathrm{S} 2$ 宇 $\mathrm{S} 3$ 官 $\mathrm{S} 4$ highest value of $\mathrm{Fe}$ in blood during all sampling seasons and sites. Fe values in feces ranged from 8.04 to 11.16 $\mathrm{mg} / \mathrm{Kg}$ at both sites of all seasons. Minimum level of $\mathrm{Fe}$ in feces was observed in season 1, at site 1 and maximum level was observed in season 2 , at site 2 . Results of Fe during all seasons in urine varied from 7.64 to $10.83 \mathrm{mg} / \mathrm{L}$. Season 2 of site 2 showed the maximum Fe value and season 1 of site 1 showed the minimum Fe value in urine (Fig. 3).

Fig. 3. Mean concentration of $\mathrm{Fe}$ and $\mathrm{Zn}$ in blood, urine and feces in different seasons at two sites.

Table 3. Mean concentrations and standard errors of Fe and $\mathrm{Zn}$ (in different sources and stages of goats)

\begin{tabular}{|c|c|c|c|c|c|c|c|}
\hline Stage & Source & Fe Means & Fe Std. Dev. & Fe Std. Err. & Zn Means & Zn Std.Dev. & Zn Std. Err. \\
\hline \multirow[t]{3}{*}{ Does } & Blood (mg/L) & 2.057188 & 0.297748 & 0.033289 & 1.194 & 0.304589 & 0.034054 \\
\hline & Feces $(\mathrm{mg} / \mathrm{Kg})$ & 9.72875 & 1.490243 & 0.166614 & 1.094625 & 0.297612 & 0.033274 \\
\hline & Urine $(\mathrm{mg} / \mathrm{L})$ & 9.431875 & 1.430776 & 0.159966 & 1.044625 & 0.297612 & 0.033274 \\
\hline \multirow{3}{*}{ Bucks } & Blood (mg/L) & 2.00625 & 0.275454 & 0.030797 & 1.09625 & 0.264156 & 0.029533 \\
\hline & Feces $(\mathrm{mg} / \mathrm{Kg})$ & 9.529688 & 1.362815 & 0.152367 & 0.9905 & 0.270318 & 0.030222 \\
\hline & Urine $(\mathrm{mg} / \mathrm{L})$ & 9.233438 & 1.35896 & 0.151936 & 0.9405 & 0.270318 & 0.030222 \\
\hline \multirow[t]{3}{*}{ Wether } & Blood (mg/L) & 2.004438 & 0.28607 & 0.031984 & 1.095625 & 0.273865 & 0.030619 \\
\hline & Feces $(\mathrm{mg} / \mathrm{Kg})$ & 9.527813 & 1.387107 & 0.155083 & 0.9965 & 0.273323 & 0.030558 \\
\hline & Urine $(\mathrm{mg} / \mathrm{L})$ & 9.245625 & 1.406015 & 0.157197 & 0.9465 & 0.273323 & 0.030558 \\
\hline \multirow[t]{3}{*}{ Juvenile } & Blood (mg/L) & 2.0295 & 0.273633 & 0.030593 & 1.120813 & 0.265785 & 0.029716 \\
\hline & Feces $(\mathrm{mg} / \mathrm{Kg})$ & 9.64375 & 1.36331 & 0.152423 & 1.021 & 0.266442 & 0.029789 \\
\hline & Urine $(\mathrm{mg} / \mathrm{L})$ & 9.291875 & 1.407017 & 0.157309 & 0.971688 & 0.266507 & 0.029796 \\
\hline Over all & & 6.977516 & 3.690632 & 0.119115 & 1.042719 & 0.285749 & 0.009223 \\
\hline
\end{tabular}


Fe concentrations in the blood plasma of goats were lower than the permissible concentration $(2.5 \mathrm{mg} / \mathrm{L})$ described by Kaneko (1980). Fe values in the blood plasma in the present study were lower than the values mentioned by Kalita et al. (2006). Fe values in the blood were also lower than the limits described by Schweinzer et al. (2017). Feces analysis showed that the Fe concentration in feces were lower than the values reported by Mnkeni and Austin (2009) and Khan et al. (2003). Fe level in urine of goats was higher than the results determined by Abulude et al. (2006). Iron is an indispensable nutrient which plays a considerable role in many metabolic processes and has significant importance in organisms. A large portion of Iron is a vital component of protein like myoglobin and hemoglobin (Suttle, 2010).

Amount of Fe in dietary food varies according to food type. Plant species and soil in which plant grows and availability of $\mathrm{Fe}$ to ruminants are the main factors which determine the Fe concentration in ruminants. There are many serious diseases which are associated with Fe deficiency like anemia, poor immune system, weakness and slow growth (Herdt and Hoff, 2011). Many other factors also cause the Fe deficiency. Trace elements reduce the Fe availability, for example, excess amount of Mn and Co may inhibit the Fe availability. Excretion of $\mathrm{Fe}$ by urine and feces may also be a possibility of Fe deficiency (Hallberg and Hulthen, 2000). Iron deficiency in the present study may be associated with the low Fe level in soil and forages and high amount of other trace metals.

Zinc (Zn). Soil. Analysis of variance of the data for $\mathrm{Zn}$ showed significant $(\mathrm{P}<0.05)$ variation in site, season and site $\mathrm{x}$ season in soil (Table 2). $\mathrm{Zn}$ level in soil varied from 2.02 to $4.81 \mathrm{mg} / \mathrm{Kg}$. The minimum value of $\mathrm{Zn}$ in soil was observed in season 1 , at site 1 and maximum value was observed in season 4 , at site 2 (Fig. 2). $\mathrm{Zn}$ values in soil samples of the present study were much lower than the critical level $(60 \mathrm{mg} / \mathrm{Kg})$ mentioned by WHO (2000). Zn soil findings of the present study were equal to the findings of Orisakwe et al. (2017) in soil. The present $Z n$ value of soil was lower than the critical level of Zn in soil reported by Sanchez (1976).

$\mathrm{Zn}$ is an important element which plays a significant role in enzymatic reactions, but the level of $\mathrm{Zn}$ in soil depends on the type of soil (Knezevic et al., 2009). The main factors which are responsible for the $\mathrm{Zn}$ content in soil are the extent of weathering process and chemical composition of natural rock (Chesworth, 1991). Sandy soil contains the lowest $\mathrm{Zn}$ content, and organic and calcareous soil contain the highest $\mathrm{Zn}$ content. Overall worldwide mean level of $\mathrm{Zn}$ in soils is $64 \mathrm{mg} / \mathrm{Kg}$. In the present study, Level of $\mathrm{Zn}$ can increase in $\mathrm{Zn}$ deficit soil by direct application of liquid $\mathrm{Zn}$ fertilizer other than granular fertilizers (Mertens et al., 2013). The lower level of $\mathrm{Zn}$ in soil was due to sandy soil because sandy soil contains low amount of $\mathrm{Zn}$.

Forages. Variance analysis of $\mathrm{Zn}$ data in forages showed significant $(\mathrm{P}<0.05)$ effect in site but non-significant $(P>0.05)$ effect in season and site $x$ season (Table 2). Concentration of $\mathrm{Zn}$ in forages ranged from 31.87 to $32.66 \mathrm{mg} / \mathrm{Kg}$ in all seasons of both sites. Data revealed that the lowest $\mathrm{Zn}$ value in forages was present in season 1 , at site 1 and the highest concentration was present in season 3, at site 2 (Fig. 2). $\mathrm{Zn}$ level in the forages investigated in the present study was below the permissible value $(50 \mathrm{mg} / \mathrm{Kg})$ suggested by $\mathrm{WHO}$ (1998). Zn level in forages in the present study was higher than the values described by Moreki et al. (2013) but these values were equal to the minimum $\mathrm{Zn}$ dietary requirement level recommended by McDowell et al. (1982).

Zn plays a vital role in plants by performing many essential functions like photosynthesis, membrane structure, gene expression and regulation, lipids and nucleic acids metabolism, phyto hormone activity, protein synthesis and defense against disease and drought (Begum et al., 2016). Manganese and phosphorus are the main factors which cause to low the $\mathrm{Zn}$ level in forages. Forage growth effect severely due to deficiency of $\mathrm{Zn}$ because $\mathrm{Zn}$ deficiency reduces plant growth and yield (Rosen and Eliason, 2005). Alkaline calcareous soil reduce the availability of $\mathrm{Zn}$ to crops from the soil because $\mathrm{Zn}$ absorbed on calcareous soil and not available to plants (Cakmak, 2008). In the present study, $\mathrm{Zn}$ level in forages was below the limits which might be due to high levels of phosphorus and manganese.

Goats. Results of $\mathrm{Zn}$ in goats depicted that $\mathrm{Zn}$ was significantly $(\mathrm{P}<0.05)$ affected by site and site $\mathrm{x}$ season, but non-significantly $(\mathrm{P}>0.05)$ affected by season (Table 2). Level of $\mathrm{Zn}$ in goats was present in between $0.74-1.35 \mathrm{mg} / \mathrm{Kg}$ in all seasons of both sites. The lowest $\mathrm{Zn}$ level was present in season 2, at site 1 and the highest level was present in season 2, at site 2 (Fig. 2). The present results also revealed that $\mathrm{Zn}$ concentration in goats was significantly affected $(P<0.05)$ in source 
and stage, but non-significantly $(\mathrm{P}>0.05)$ affected in source $x$ stage (Table 2). Zn values in source and stages varied from 0.94 to $1.19 \mathrm{mg} / \mathrm{Kg}$ (Table 3 ). $\mathrm{Zn}$ concentration in urine of bucks was present at minimum level and $\mathrm{Zn}$ concentration in blood of does present at maximum level.

Box plot showed that $\mathrm{Zn}$ values of all seasons at both sites in blood plasma were ranged from 0.82 to 1.43 $\mathrm{mg} / \mathrm{L}$. Season 2 of site 1 and site 2 depicted the minimum and maximum level of $\mathrm{Zn}$ in blood, respectively. $\mathrm{Zn}$ concentration in feces was observed from 0.72 to 1.33 $\mathrm{mg} / \mathrm{Kg}$ during all seasons of both sites. The lowest concentration of $\mathrm{Zn}$ feces was present at site 1 in season 2 and the highest concentration was present at site 2 in season 2. Results of $\mathrm{Zn}$ in urine varied from 0.67 to $1.28 \mathrm{mg} / \mathrm{L}$ in all sampling seasons of both sites. Season 2 at site 1 and site 2 was responsible for the lowest and highest concentration of $\mathrm{Zn}$ urine in animal (Fig. 3). $\mathrm{Zn}$ concentration of blood samples in the present study was lower than the permissible limits $(1.45 \mathrm{mg} / \mathrm{L})$ recommended by FAO/WHO (2001) and NRC (2007). Present recorded value of blood $\mathrm{Zn}$ was also equal to the study of Milam et al. (2017). In the present investigation, the level of $\mathrm{Zn}$ in feces was lower than the level of $\mathrm{Zn}$ given by Mnkeni and Austin (2009) and Odedina et al. (2011). Urine level of $\mathrm{Zn}$ observed in the current study was below the level described by Abulude et al. (2006) and Khaniki (2005).

Zinc is an essential element for organisms. It exists as the number one rank intracellular trace element according to its abundance and second in overall abundance in the body after iron. It plays a vital role in many functions like it known as an essential component of many enzymes and assist in catalytic, regulatory and structural functions within the body (Cousins, 2006).

Toxicity of Zinc is not present at large scale in the world. Many organisms show Zn deficiency because phytate with combination of calcium cause to reduce the availability of Zinc to animals. Zn deficiency in ruminants is not so common because ruminants are very blessed by nature because in ruminants' phytate is digested by microbes of the rumen. Regular cutting of grasses in one season and straw of mature forages have low $\mathrm{Zn}$ level and feeding on these can be the reason of $\mathrm{Zn}$ deficiency in ruminants (Herdt and Hoff, 2011). Symptoms of $\mathrm{Zn}$ deficiency are poor growth, poor intake of food, poor immune system, skin thickening and hair loss (Nagalakshmi et al., 2009). In the present study, $\mathrm{Zn}$ deficit crop might be one of the main reasons of $\mathrm{Zn}$ deficiency in ruminants and $\mathrm{Zn}$ containing supplementation is compulsory in the diet of these goats.

Bio-concentration factor. Iron $(\mathrm{Fe})$. Bio-concentration factor $(\mathrm{BCF})$ for $\mathrm{Fe}$ in forages was ranged from 1.78 to 2.63 at two sites in all seasons. Lowest $\mathrm{BCF}$ of $\mathrm{Fe}$ was present in season 2 at site 1 and highest $\mathrm{BCF}$ was present in season 3 at site 2 . BCF of Fe in goats varied from 0.214 to 0.245 at two sites in all seasons. Minimum $\mathrm{BCF}$ of Fe in goats was present in season 1 at site 1 and the maximum was in season 2 at site 2 (Table 4 ).

Bio-concentration factor for $\mathrm{Fe}$ in forages at all sites was greater than 1 indicated its more availability to plants and less retention in soil. Ahmad et al. (2018a) also recorded higher transfer of $\mathrm{Fe}$ (6.26-6.79) from soil to plant as compared to present findings. The values of $\mathrm{BCF}$ for Fe in current work were lower than the findings of Ahmad et al. (2018b).

Table 4. Mean concentrations of bio-concentration factor of metals

\begin{tabular}{|c|c|c|c|c|c|c|c|}
\hline \multicolumn{4}{|c|}{ Soil to forages } & \multicolumn{4}{|c|}{ Forages to goats } \\
\hline Site & Season & $\mathrm{Fe}$ & $\mathrm{Zn}$ & Site & Season & $\mathrm{Fe}$ & $\mathrm{Zn}$ \\
\hline \multirow[t]{5}{*}{ Site-1 } & & & & Site-1 & & & \\
\hline & S1 & 2.251017 & 15.77049 & & S1 & 0.214322 & 0.024561 \\
\hline & S2 & 1.786787 & 8.057521 & & S2 & 0.216141 & 0.023024 \\
\hline & $\mathrm{S} 3$ & 1.816986 & 10.32212 & & S3 & 0.232893 & 0.02482 \\
\hline & $\mathrm{S} 4$ & 1.940664 & 8.88254 & & $\mathrm{~S} 4$ & 0.218428 & 0.026698 \\
\hline \multirow[t]{5}{*}{$\underline{\text { Site-2 }}$} & & & & Site-2 & & & \\
\hline & $\mathrm{S} 1$ & 2.23391 & 9.199053 & & $\mathrm{~S} 1$ & 0.243557 & 0.039623 \\
\hline & S2 & 2.184093 & 7.307851 & & $\mathrm{~S} 2$ & 0.245047 & 0.041484 \\
\hline & S3 & 2.630207 & 11.57533 & & $\mathrm{~S} 3$ & 0.236772 & 0.03914 \\
\hline & S4 & 1.907157 & 6.733616 & & $\mathrm{~S} 4$ & 0.227358 & 0.038389 \\
\hline
\end{tabular}


Zinc (Zn). BCF for $\mathrm{Zn}$ in forages was present in between 6.73 to 15.77 at two sites in all seasons. The minimum value of BCF was observed in season 4 site 2 and maximum value of $B C F$ was observed in season 1 site 1. $\mathrm{BCF}$ for $\mathrm{Zn}$ in goats at two sites in all seasons was ranged from 0.023 to 0.041 . Minimum and maximum $\mathrm{BCF}$ for $\mathrm{Zn}$ in goats were existed in season 2 at site 1 and site 2 respectively (Table 4 ).

Bio-concentration factor for $\mathrm{Zn}$ in forages was greater than 1. The BCF depicted the greater transfer of $\mathrm{Zn}$ from soil to plant. Lokeshwari and Chandrappa (2006) stated that $\mathrm{Zn}$ retained less in soil, hence, it is more mobile than other heavy metals. The values of BCF for $\mathrm{Zn}$ in current research were higher than the values recorded by Alghobar and Suresha (2015).

Pollution load index. Iron (Fe). Results showed that pollution load index (PLI) for Fe varied from 0.21 to 0.30 in all sampling seasons at both sites. Minimum PLI for Fe in the soil was present at site 1 in season 1 and maximum PLI for Fe was present in season 4 at site 2 (Table 5).

The values of PLI for Fe in current work were lower than the reference values of Fe (56.90) suggested by Dosumu et al. (2005). The values of PLI greater than unity indicate that the soil is contaminated, while less than unity shows soil is un-contaminated (Jorfi et al., 2017). The value of PLI for Fe in present work was less than unity.

Zinc (Zn). The pollution load index for $\mathrm{Zn}$ in soil was ranged from 0.045 to 0.108 in all seasons at site 1 and site 2. Lowest level of PLI for Zn was observed in season 1 and highest was observed in season 4 at site 1 and site 2 respectively (Table 5).

Pollution severity and its variation among sites is determined by using pollution load index. The value of PLI for $\mathrm{Zn}$ in present findings were lower than the reference values of $\mathrm{Zn}$ (44.19) given by Singh et al. (2010). Mohamed et al. (2014) reported the higher value of PLI for $\mathrm{Zn}$ (7.57) as compared to present findings.

Enrichment factor. Iron (Fe). Results of Fe showed that enrichment factor (EF) of Fe was ranged from 0.23 to 0.35 in all seasons at both sites. Maximum level of the $\mathrm{EF}$ of $\mathrm{Fe}$ was present in season 3 at site 2 and the minimum level of the $\mathrm{EF}$ of $\mathrm{Fe}$ was present in season 2 at site 1 (Table 5). Iron EF showed no significant variation with respect to season. Present investigation showed that iron E.F was lower than the values of Likuku et al. (2013) and Alghobar and Suresha (2015). Standards of Barbieri (2016) categorize the iron E.F into the deficient category.

Zinc (Zn). Data of EF for $\mathrm{Zn}$ varied from 2.99 to 7.01 in all seasons at both sites. Maximum EF was existed at site 1 in season 1 and minimum EF for $\mathrm{Zn}$ was existed at site 2 in season 4 (Table 5). Zinc EF of the current study was equal as described by Ezemokwe et al. (2017). Current Zn E.F was present in deficient enrichment according to standards given by Barbieri et al. (2016).

Table 5. Mean concentrations of pollution load index and enrichment factor of metals

\begin{tabular}{|c|c|c|c|c|c|c|c|}
\hline \multicolumn{4}{|c|}{ Pollution load index of metals } & \multicolumn{4}{|c|}{ Enrichment factor } \\
\hline Site & Season & $\mathrm{Fe}$ & $\mathrm{Zn}$ & Site & Season & $\mathrm{Fe}$ & $\mathrm{Zn}$ \\
\hline \multirow[t]{4}{*}{ Site-1 } & $\mathrm{S} 1$ & 0.211147 & 0.045736 & \multirow[t]{4}{*}{ Site-1 } & $\mathrm{S} 1$ & 0.301017 & 7.011046 \\
\hline & $\mathrm{S} 2$ & 0.281336 & 0.090966 & & $\mathrm{~S} 2$ & 0.238938 & 3.582111 \\
\hline & $\mathrm{S} 3$ & 0.262953 & 0.070063 & & $\mathrm{~S} 3$ & 0.242977 & 4.588879 \\
\hline & $\mathrm{S} 4$ & 0.248993 & 0.081263 & & $\mathrm{~S} 4$ & 0.259515 & 3.948888 \\
\hline \multirow[t]{4}{*}{ Site-2 } & $\mathrm{S} 1$ & 0.258408 & 0.080262 & \multirow[t]{4}{*}{ Site-2 } & $\mathrm{S} 1$ & 0.29873 & 4.089599 \\
\hline & $\mathrm{S} 2$ & 0.266387 & 0.100943 & & $\mathrm{~S} 2$ & 0.292068 & 3.248833 \\
\hline & $\mathrm{S} 3$ & 0.220962 & 0.063855 & & $\mathrm{~S} 3$ & 0.351725 & 5.146014 \\
\hline & $\mathrm{S} 4$ & 0.306524 & 0.108979 & & $\mathrm{~S} 4$ & 0.255035 & 2.993546 \\
\hline
\end{tabular}

Pollution Load Index

Reference values $(\mathrm{mg} / \mathrm{Kg})$ of soil Fe and $\mathrm{Zn}$ are 56.80 and 44.19; Sources: Singh et al., 2010, Dosumu et al., 2005.

Enrichment Factor

Reference values $(\mathrm{mg} / \mathrm{Kg})$ soil of Fe and $\mathrm{Zn}$ are 56.80 and 44.19; Sources: Singh et al., 2010, Dosumu et al., 2005; Reference values $(\mathrm{mg} / \mathrm{Kg}$ ) forage of Fe and $\mathrm{Zn}$ are 425.5 and 99.4; Sources: FAO/WHO (2001). 


\section{Conclusion}

Sites variations are much rather than seasonal variations. Level of iron and zinc were much lower in soil, forages and ruminants. Iron level in blood of ruminants was within permissible levels. Bio-concentration factor of $\mathrm{Zn}$ was higher from soil to forage but other indices were lower from toxic level. Overall iron and zinc showed a deficit level which might be due to unavailability of these minerals in the diet of ruminants. This deficiency can be fulfilled by providing a mineral mixture containing high amount of iron and zinc.

\section{Acknowledgement}

The authors are grateful to The Higher Education Commission, Pakistan for providing funds through research project no. 20-3546/NRPU/R\&D/HEC/14/536. We are also thankful to local people of area for providing help in research work.

Conflict of Interest. The authors declare no conflict of interest.

\section{References}

Abulude, F.O., Eluyode, O.S., Jegede, A.T. 2006. An investigation into the effect of traffic pollution on the levels of some heavy metals in goats urine sample. Journal of Animal and Veterinary Advances, 5: 132-134.

Ackova, D.G. 2018. Heavy metals and their general toxicity on plants. Plant Science Today, 5: 14-18.

Ahmad, K., Ashfaq, A., Khan, Z.I., Bashir, H., Sohail, M., Mehmood, N., Dogan, Y. 2018a. Metal accumulation in Raphanus sativus and Brassica rapa: an assessment of potential health risk for inhabitants in Punjab, Pakistan. Environmental Science and Pollution Research, 25: 16676-16685.

Ahmad, K., Kokab, R., Khan, Z.I., Ashfaq, A., Bashir, H., Munir, M., Sher, M., Wajid, K., Memona, H., Sana, M., Noorka, I.R., Shehzadi, M., Nadeem, M., Qureshi, T.M., Mehmood, N., Ijaz, A., Huma, B., Malik, I.S., Nawaz, K., Ugulu, I., Dogan, Y. 2018b. Assessment of heavy metals in wheat variety "Chagi-2" under short-term wastewater irrigation. Biologia, 64: 15-25.

Alghobar, M.A., Suresha, S. 2015. Evaluation of nutrients and trace metals and their enrichment factors in soil and sugarcane crop irrigated with wastewater. Journal of Geoscience and Environmental Protection, 3: 46-56.
Barbieri, M. 2016. The importance of enrichment factor (ef) and geoaccumulation index (igeo) to evaluate the soil contamination. Journal of Geology and Geophysics, 5: 237-242.

Begum, M.C., Islam, M., Sarkar, M.R., Azad, M.A.S., Huda, A.N., Kabir, A.H. 2016. Auxin signaling is closely associated with Zn efficiency in rice (Oryza sativa L.). Journal of Plant Interaction, 11: 124129.

Buat-Menard, P., Chesselet, R. 1979. Variable influence of atmospheric flux on the trace metal chemistry of oceanic suspended matter. Earth and Plant Science Letters, 42: 398-411.

Cakmak, I. 2008. Zinc deficiency in wheat in Turkey, In: Micronutrient Deficiencies in Global Crop Production, Alloway, B. (eds.), pp. 181-200, Springer, The Netherlands.

Chesworth, W. 1991. Geo-chemistry of micronutrients, In: Micronutrients in Agriculture, Second Edition, Mortvedt, J.J., Cox, F.R., Shuman, L.M., Welch, R.M. (eds.), Soil Science Society of America, Madison, WI: 1-30.

Cousins, R.J. 2006. Zinc. In: Present Knowledge in Nutrition, Bowman, B.A., Russell, R.M. (eds.), $9^{\text {th }}$ edition, vol. 1, pp. 445-457, International Life Sciences Institute, Washington, DC, USA.

Cui, Y.J., Zhu, Y.G., Zhai, R.H., Chen, D.Y., Huang, Y.Z., Qui, Y., Liang, J.Z. 2004. Transfer of metals from near a smelter in Nanning, China. Environment International, 30: 785-791.

Dorlodot, S., Lutts, S., Bertin, P. 2005. Effects of ferrous iron toxicity on the growth and mineral composition of an inter specific rice. Journal of Plant Nutrition, 28: $1-20$.

Dosumu, O.O., Salam, N.A., Oguntoy, N.S. 2005. Trace metals bio-accumulation by some Nigerian vegetables. Centrepoint, 13: 23-32.

Eng, J.M.D. 2003. Sample size estimation: how many individuals should be studied. Radiology, 227: 309313.

Ezemokwe, D.E., Ichu, C.B., Okoro, J.N., Opara, A.I. 2017. Evaluation of heavy metal contamination of soils alongside awka-enugu road, southeastern Nigeria. Asian Journal of Environment and Ecology, 4: 1-11.

Food and Agricultural Organization (FAO/WHO). 2001. Codex Alimentarius Commission. Food Additive and Contaminants. Joint $\mathrm{FAO} / \mathrm{WHO}$ food standards programme, Alinorm 01/12A, pp. 1-289.

Hallberg, L., Hulthen, L. 2000. Prediction of dietary 
iron absorption: an algorithm for calculating absorption and bioavailability of dietary iron. American Journal of Clinical Nutrition, 71: 11471160.

Hansch, R., Mendel, R.R. 2009. Physiological functions of mineral micronutrients $(\mathrm{Cu}, \mathrm{Zn}, \mathrm{Mn}, \mathrm{Fe}, \mathrm{Ni}, \mathrm{Mo}$, $\mathrm{B}, \mathrm{Cl})$. Current Opinion in Plant Biology, 12: 259266.

Herdt, T.H., Hoff, B. 2011. The use of blood analysis to evaluate trace mineral status in ruminant livestock. Veterinary Clinics of North America: Food Animal Practice, 27: 255-283.

Incesu, M., Yesiloglu, T., Cimen, B., Yilmaz, B. 2015. Influences of different iron levels on plant growth and photosynthesis of W. Murcott mandarin grafted on two rootstocks under high $\mathrm{pH}$ conditions. Turkish Journal of Agriculture and Forestry, 39: 838-844.

Irmak, S., Kasap, Y., Surucu, A. 2007. Effects of town waste on the heavy metal contents and plant nutrient element contents of soils in harran plain, Turkey. Fresenius Environmental Bulletin, 16: 285-289.

Jorfi, S., Maleki, R., Jaafarzadeh, N., Ahmadi, M. 2017. Pollution load index for heavy metals in Mian-Ab plain soil, Khuzestan, Iran. Data in Brief, 15: 584590.

Kalaivanan, D., Ganeshamurthy, A.N. 2016. Mechanisms of heavy metal toxicity in plants. In: Abiotic Stress Physiology of Horticultural Crops, pp. 85102, Springer, New Delhi, India.

Kalita, D.J., Sarmah, B.C., Bhattacharyya, B.N., Milli, D.C. 2006. Serum mineral profile of assam local goat of hills zone during different physiological stages. Indian Journal of Animal Research, 40: 9394.

Kamada, H., Nishimura, H.K., Krongyuti, P., Sukkasame, P., Phoengpong, N., Intramanee, N. 2000. Selenium status of soil, herbage and beef cattle in southern Thailand. Journal of Dairy Sciences, 82: 429-437.

Kaneko, J.J. 1980. Clinical Biochemistry of Domestic Animals, $3^{\text {rd }}$ edition, pp. 649-668, Academic Press Inclusions, USA.

Khan, Z.I., Hussain, A., Ashraf, M., Valeem, E.E., Ashraf, M.Y., Ahmad, M.S. 2004. Soil and forage mineral (trace elements) status of a grazing pasture in the semiarid region of Pakistan. Pakistan Journal of Botany, 36: 851-856.

Khan, Z.I., Hussain, A., Ashraf, M., Ashraf, M.Y., Rahman, Z. 2003. Assessment of iron status of different classes of goats grazing the natural pasture during different seasons. Pakistan Journal of Life Sciences, 1: 80-86.

Khaniki, G.R.J. 2005. Determination of Zn contents in Iranian flat breads. Pakistan Journal of Nutrition, 4: 294-297.

Knezevic, M., Stankovic, D., Krstic, B., Nikolic, M.S., Vilotic, D. 2009. Concentrations of heavy metals in soil and leaves of plant species Paulownia elongata and Paulownia fortunei. African Journal of Biotechnology, 8: 5422-5429.

Lee, C.W., Choi, J.M., Pak, C.H. 1996. Micronutrient toxicity in seed geranium (Pelargonium $x$ Hortorum bailey). Journal of American Society for Horticultural Science, 121: 77-82.

Likuku, A.S., Mmolawa, K.B., Gaboutloeloe, G.K. 2013. Assessment of heavy metal enrichment and degree of contamination around the copper-nickel mine in the Selebi Phikwe Region, Eastern Botswana. Environment and Ecological Research, 1: $32-40$

Liu, W.H., Zhao, J.Z., Ouyang, Z.Y., Soderlund, L., Liu, G.H. 2005. Impacts of sewage irrigation on heavy metals distribution and contamination in Beijing, China. Environment International, 31: 805-812.

Lokeshwari, H., Chandrappa, G.T. 2006. Impact of heavy metal contamination of Bellandur lake on soil and cultivated vegetation. Current Science, 91: 622-627.

Ma, J.F., Ling, H.Q. 2009. Iron for plants and humans. Plant and Soil, 325: 1-3.

McAfee, A.J., McSorley, E.M., Cuskelly, G.J., Moss, B.W., Wallace, J.M., Bonham, M.P., Fearon, A.M. 2010. Red meat consumption: an overview of the risks and benefits. Meat Science, 84: 1-13.

McDowell, L.R., Kiatoko, M., Bertrand, J.E., Chapman, H.L., Pate, F.M., Martin, F.G., Conrad, J.H. 1982. Evaluating the nutritional status of beef cattle herds from four soil order regions of Florida. II. Trace minerals. Journal of Animal Sciences, 55: 38-47.

Mertens, J., Smolders, E. 2013. Zinc. In: Heavy Metals in Soils: Trace Metals and Metalloids in Soils and their Bio-availability, Alloway, B.J. (eds.), pp. 465493, Springer, Dordrecht, Nederlands.

Mielki, G.F., Novais, R.F., Ker, J.C., Vergütz, L., Castro, G.F.D. 2016. Iron availability in tropical soils and iron uptake by plants. Revista Brasileira de Ciencia do Solo, 40: 1-6.

Milam, C., One, M.B., Dogara, R.K., Yila, E.Y. 2017. Assessment of heavy metals (As, $\mathrm{Cd}, \mathrm{Cr}, \mathrm{Cu}, \mathrm{Ni}$, 
$\mathrm{Pb}$ and $\mathrm{Zn}$ ) in blood samples of sheep and rabbits from jimeta-yola, adamawa State, Nigeria. International Journal of Advance Pharmacy Biology and Chemistry, 6: 160-166.

Mnkeni, P.N.S., Austin, L.M. 2009. Fertilizer value of human manure from pilot urine-diversion toilets. Water SA, 35: 133-138.

Mohamed, T.A., Mohamed, M.A.K., Rabeiy, R., Ghandour, M.A. 2014. Application of pollution indices for evaluation of heavy metals in soil close to phosphate fertilizer plant, Assiut, Egypt. Assiut University Bulletin for Environmental Research, 17: 45-55.

Moreki, J.C., Woods, T.O., Nthoiwa, P.G. 2013. Estimation of the concentration of heavy metals in forages harvested around Dibete area, Botswana. International Journal of Innovative Research Science Engineering and Technology, 2: 4060-4071.

Nagajyoti, P.C., Lee, K.D., Sreekanth, T.V.M. 2010. Heavy metals, occurrence and toxicity for plants: a review. Environmental Chemistry Letters, 8: 199216.

Nagalakshmi, D., Dhanalakshmi, K., Himabindu, D. 2009. Effect of dose and source of supplemental zinc on immune response and oxidative enzymes in lambs. Veterinary Research Communications, 33: 631-644.

National Research Council (NRC). 2007. Nutrient Requirements of Domestic Animals, 1 pp., National Academy of Science Press, Washington, DC, USA.

National Research Council (NRC). 2001. Nutrient Requirements of Domestic Animals, 1 pp., National Academy of Science Press, Washington, DC, USA.

Odedina, J.N., Odedina, S.A., Ojeniyi, S.O. 2011. Effect of types of manure on growth and yield of cassava (Manihot esculenta, Crantz). Researcher, 3: 1-8.

Orisakwe, O.E., Oladipo, O.O., Ajaezi, G.C., Udowelle, N.A. 2017. Horizontal and vertical distribution of heavy metals in farm produce and livestock around lead-contaminated goldmine in Dareta and Abare, Zamfara state, northern Nigeria. Journal of Environmental and Public Health, 2017: 1-12.

Oruc, H.H., Uzunoglu, I., Cengiz, M. 2009. Suspected iron toxicity in dairy cattle. Uludag University. Journal of the Faculty of Veterinary Medicine, 28: 75-77.

Osweiler, G.D., Carlson, T.L., Buck, W.B., Von Gelder, G.A. 1985. Iron, Clinical and Diagnostic Veterinary Toxicology. $3^{\text {rd }}$ edition, pp.104-106, Kendal/Hunt, Iowa.
Page, V., Feller, U. 2015. Heavy metals in crop plants: transport and re-distribution processes on the whole plant level. Agronomy, 5: 447-463.

Ravet, K., Touraine, B., Boucherez, J., Briat, J.F., Gaymard, F., Cellier, F. 2009. Ferritins control interaction between iron homeostasis and oxidative stress in Arabidopsis. Plant Journal, 57: 400412.

Rhue, R.D., Kidder, G. 1983. Analytical Procedures Used by the IFAS Extension Soil Testing Laboratory and the Interpretation of Results. Soil Science Department, University of Florida, Gainesville.

Ricachenevsky, F.K., Sperotto, R.A. 2014. There and back again, or always there. The evolution of rice combined strategy for Fe uptake. Frontiers in Plant Sciences, 5: 189.

Rosen, C.J., Eliason, R. 2005. Nutrient Management for Commercial Fruit and Vegetable Crops in Minnesota, University of Minn, 1 pp., Extension Service.

Sanchez, P.A. 1976. Properties and Management of Soils in the Tropics. 1 pp., John Wiley and Sons, New York, USA.

Schulte, E.E. 2004. Soil and applied iron. Understanding Plant Nutrients, 1-2.

Schweinzer, V., Iwersen, M., Drillich, M., Wittek, T., Tichy, A., Mueller, A., Krametter-Froetscher, R. 2017. Macromineral and trace element supply in sheep and goats in Austria. Veterinari Medicina, 62: $62-73$.

Shisia, K.S., Ngure, V., Nyambaka, H., Oduor, F.D.O. 2013. Effect of $\mathrm{pH}$ and forage species on mineral concentrations in cattle breeds in major grazing areas of Uasin Gishu county, Kenya. International Journal of Current Microbiology and Applied Sciences, 2: 247-254.

Singh, A., Sharma, R.K., Agrawal, M., Marshall, F.M. 2010. Health risk assessment of heavy metals via dietary intake of food stuffs from the wastewater irrigated site of a dry tropical area of India. Food and Chemical Toxicology, 48: 611-619.

Soetan, K.O., Olaiya, C.O., Oyewole, O.E. 2010. The importance of mineral elements for humans, domestic animals and plants: a review. African Journal of Food Science, 4: 200-222.

Sperotto, R.A., Ricachenevsky, F.K., Stein, R.J., Waldow, V.A., Fett, J. P. 2010. Iron stress in plants: dealing with deprivation and overload. Plant Stress, 4: 57 69.

Steel, R.G.D., Torrie, J.H., Dickey, D.A. 2006. Principles 
and Procedures of Statistics. A Biometrical Approach, $3^{\text {rd }}$ edition, McGraw Hill Company, New York, USA.

Suttle, N.F. 2010. Mineral Nutrition of Livestock, $4^{\text {th }}$ edition, 1 pp., Midlothian, UK.

Versieren, L., Evers, S., AbdElgawag, H., Asard, H., Smolders, E. 2017. Mixture toxicity of copper, cadmium, and zinc to barley seedlings is not explained by antioxidant and oxidative stress biomarkers. Environmental Toxicology and Chemistry, 36: $220-230$.

White, P.J., Greenwood, D.J. 2013. Properties and management of cationic elements for crop growth.
In: Soil Conditions and Plant Growth, Gregory, P.J., Nortcliffe, S. (eds.), $12^{\text {th }}$ edition, pp. 160-194, Blackwell Publishing, Oxford, UK.

Wood, R.J. 2000. Assessment of marginal zinc status in humans. The Journal of Nutrition, 130: 13501354.

World Health Organization (WHO). 1998. Quality Control Methods for Medicinal Plant Materials, 1 pp., Geneva, Switzerland.

World Health Organization (WHO). 2000. Safety evaluation of certain food additives and contaminants. International programme on chemical safety. WHO Food Additive Series, 52: 1. 